\title{
Making It Work: Developing a Student-Centered Assessment Model for a Large-Scale Information Literacy Program
}

\author{
Rachel W. Gammons and Lindsay Inge \\ University of Maryland, USA
}

\begin{abstract}
Information literacy instruction presents a difficult balance between quantity and quality, particularly for large-scale general education courses. This paper discusses the overhaul of the freshman composition instruction program at the University of Maryland Libraries, focusing on the transition from survey assessments to a student-centered and mixedmethods approach using qualitative reflections, rubrics, and the evaluation of student artifacts.

\section{Introduction}

Information literacy instruction presents a difficult balance between quantity and quality, particularly for large-scale general education courses. The desire to provide high-quality instruction often conflicts with the realities of staffing, space, budgets, and time. For the University of Maryland (UMD) Libraries, this is best demonstrated in the instruction program for freshman composition, formerly known as "Library Day." Extending as far back as 1995, "Library Day" has formed the foundation of first year programming in the libraries. Each year, the libraries provide information literacy instruction to 95\% of English 101 sections, leading an average of 215 sessions across the fall and spring semesters.
\end{abstract}

Early on, the demand for instruction outpaced the capacity of User Education Services (UES), which managed its operation. In 1999, UES began meeting the demand by hiring part-time special lecturers, a practice which continues to this day. While the influx of instructors increased the ability to provide instruction, managing the program left little time for innovation or creativity, particularly within the lesson plans and assessments. By fall 2014, instructional materials and assessment methods that had been considered progressive for their time were beginning to show their age. Instruction was based on a script, which had changed little in the previous decade, and assessment centered on a four-question survey that measured students' ability to perform basic skills, such as correctly utilizing a Boolean operator. Disquiet with the program had spread outside the library, as course instructors had grown weary of sitting through the same library presentation semester after semester, year after year. Although the composition program had continued to update the syllabus and improve their assignments, the libraries had not, and the need for change was apparent.

In spring 2015, Teaching and Learning Services (TLS), formerly UES, began the process of overhauling "Library Day," starting with the learning outcomes and moving up through assessment. This paper discusses the process by which we reinvigorated this aging information literacy program, focusing on the transition from a survey-based assessment to an iterative, studentcentered, critically grounded, and outcomes-based assessment model.

\section{Pilot Program: Spring 2015}

In spring 2015, a change in leadership in the libraries and addition of new staff in TLS offered an opportunity to reimagine "Library Day" and the corresponding assessment. An increase in the number of full-time staff led to a decrease in the amount of instruction sessions led by special lecturers, down from $70 \%$ in 2014 to $50 \%$ in spring 2015. The makeup of instructors, including both faculty librarians and special lecturers, created the ideal environment for a pilot program; while the special lecturers continued to teach a modified version of Library Day, the more experienced instructors piloted an active learning-based lesson plan, which left more room for individuality and customization.

To assess the success of the pilot program, we created a simple assessment plan. At the end of the pilot session, students would be asked to share their "a-ha moment" from the learning experience. Based on the six-word memoir, this assessment would provide students with an opportunity to reflect critically on their experience and share a moment 
of personal significance. To mitigate the time needed to explain and implement the assessment during each session, the six-word framework was expanded slightly; rather than six words, students were asked to structure their "a-ha moment" responses in a 140-character tweet that included \#mylibrarymoment.

Students were given no restrictions beyond that their responses fit within a single tweet. Rather than measuring students' abilities to accomplish a specific set of skills, the "a-ha moment" was intended to challenge learners to sift through the session and share a moment of personal impact.

\section{Methods}

"A-ha moment" responses were collected from Twitter using two web-based programs: "If This Then That" (IFTTT) and "TAGS." Each of these required a "recipe," or a specific set of circumstances that, if fulfilled, prompted the systems to identify, collect, and archive the tweet. Tweets including \#mylibrarymoment were automatically copied and saved to a Google Sheet.

After piloting Twitter as a collection tool in two sessions, we quickly identified a challenge: not only had we overestimated the amount of students that were active on Twitter, but also the amount of information they were comfortable disclosing in a publicly-accessible space. Many of the students who participated in the pilot had private accounts, which meant that, even when they authored a tweet using \#mylibrarymoment, the collection tools were prohibited from accessing or archiving their tweets.

As a workaround, we added an option for students who did not have a Twitter account or had a private account to submit responses through a Google form. The Google form was connected to the same Google sheet used by IFTTT and TAGS to archive tweets using \#mylibrarymoment. All responses, regardless of whether they were collected through the Google form or Twitter, were capped at 140 characters. The Twitter assessment was piloted in 12 one-shot instruction sessions for freshman composition led by two full-time library instructors in TLS and took place between February and March of 2015. Over the course of the 12 sessions, 142 responses were collected, for a response rate of $62 \%$.

\section{Analysis}

Although the responses were interesting on their own, a systematic analysis method was necessary to identify trends in the data. In response, librarians developed a process for organizing and coding responses based on the ACRL Framework for Information Literacy. Because the "a-ha moment" was intended to measure attitudes rather than skills, a decision was made to focus the analysis on the dispositions outlined in the framework. As a team, we identified seven dispositions, pulled from five of the six frames, that best aligned with the learning outcomes for the course and represented an appropriate developmental level for first-year learners. Each "a-ha moment" response or tweet was read by the team of librarians and assigned to the disposition that best matched the content. The analysis was based on consensus, with librarians discussing each response and its appropriate placement, deliberating until a unified decision was reached.

The table below outlines the dispositions selected, types of responses assigned to each category, and percentage of responses attributed to each.

\begin{tabular}{|l|l|l|c|}
\hline Frame & Disposition & Example & $\mathbf{n}$ \\
\hline $\begin{array}{l}\text { Authority is } \\
\text { Constructed } \\
\text { and Contextual }\end{array}$ & $\begin{array}{l}\text { develop awareness of the } \\
\text { importance of assessing content } \\
\text { with a skeptical stance and with } \\
\text { self-awareness of their own } \\
\text { biases and worldview }\end{array}$ & $\begin{array}{l}\text { "Make sure a publisher is unbiased. } \\
\text { \#mylibrarymoment." }\end{array}$ & $5 \%$ \\
\hline $\begin{array}{l}\text { Information } \\
\text { has Value }\end{array}$ & $\begin{array}{l}\text { respect the original ideas of } \\
\text { others }\end{array}$ & $\begin{array}{l}\text { "Some books have more than one author, so } \\
\text { you can actually cite the different chapters as } \\
\text { different sources \#mylibrarymoment" }\end{array}$ & $6 \%$ \\
\hline $\begin{array}{l}\text { Research as } \\
\text { Inquiry }\end{array}$ & $\begin{array}{l}\text { value intellectual curiosity } \\
\text { in developing questions and } \\
\text { learning new investigative } \\
\text { methods }\end{array}$ & $\begin{array}{l}\text { “Learning how to use Research Port was really } \\
\text { helpful because I was able to find so many more } \\
\text { articles that will help me with my research" }\end{array}$ & $99 \%$ \\
\hline
\end{tabular}




\begin{tabular}{|c|c|c|c|c|}
\hline Frame & Disposition & Example & $\%$ & $\mathrm{n}$ \\
\hline $\begin{array}{l}\text { Scholarship as } \\
\text { Conversation }\end{array}$ & $\begin{array}{l}\text { recognize that scholarly } \\
\text { conversations take place in } \\
\text { various venues }\end{array}$ & $\begin{array}{l}\text { "Working with my peers to find connections } \\
\text { between our extremely different topics and } \\
\text { sharing databases that wouldn't at first seem to } \\
\text { be [applicable]." }\end{array}$ & $9 \%$ & 13 \\
\hline $\begin{array}{l}\text { Scholarship as } \\
\text { Conversation }\end{array}$ & $\begin{array}{l}\text { see themselves as contributors } \\
\text { to the scholarship rather than } \\
\text { only consumers }\end{array}$ & n/a & $0 \%$ & 0 \\
\hline $\begin{array}{l}\text { Searching } \\
\text { as Strategic } \\
\text { Exploration }\end{array}$ & $\begin{array}{l}\text { seek guidance from experts, } \\
\text { such as librarians, researchers, } \\
\text { and professionals }\end{array}$ & $\begin{array}{l}\text { "The librarians helped me get really helpful } \\
\text { information from Research Port" }\end{array}$ & $6 \%$ & 9 \\
\hline $\begin{array}{l}\text { Searching } \\
\text { as Strategic } \\
\text { Exploration }\end{array}$ & $\begin{array}{l}\text { understand that first attempts at } \\
\text { searching do not always produce } \\
\text { adequate results }\end{array}$ & $\begin{array}{l}\text { "\#mylibrarymoment was that you could use } \\
\text { synonyms to broaden your search within the } \\
\text { same topic. I usually use the same words when } \\
\text { I search." }\end{array}$ & $21 \%$ & 29 \\
\hline \multicolumn{2}{|c|}{$\begin{array}{r}\text { Other (responses that did not fit in above } \\
\text { category) }\end{array}$} & $\begin{array}{l}\text { "When I found a correlation between } \\
\text { contracting celiac diseases and consumption of } \\
\text { Genetically Modified Foods" }\end{array}$ & $4 \%$ & 5 \\
\hline \multicolumn{4}{|r|}{ Total } & 142 \\
\hline
\end{tabular}

\section{Results}

Although the pilot lesson plan had been updated to emphasize the scholarly conversation and importance of evaluating information, responses from students indicated they were not connecting with these ideas in the classroom, or, at the least, these concepts were not standing out as "a-ha moments.” Despite the reduction of in-class time spent on database demonstrations and search strategies, the dispositions surrounding searching and retrieval continued to dominate the responses, accounting for $70 \%$ of the overall responses.

Also, while we had anticipated that, being firstyear students, many of our learners would share irrelevant, irreverent, or incoherent responses, only five of the 142 responses (4\%) fell outside of the parameters of the analysis.

\section{Implications}

The pilot program was the first step in transitioning away from the quantitative and skills-based assessments associated with "Library Day." While reading and coding the "a-ha moments" required increased analysis time, the character limit made them easy to quickly read and evaluate. Using a coding method based on the ACRL framework enabled us to create meaning from what could have been a vast disparate pool of data. Organizing the results into the seven dispositions helped us better understand how our students self-identified learning outcomes connected to the stated student learning objectives for the session, overall lesson plan, and professional standards.

\section{Research and Teaching Fellowship}

While the pilot program offered exciting developments in both teaching and assessment, scaling up the program presented challenges. The active learning and critically-based instruction method utilized in the pilot would require a fundamental restructuring of the hiring and training of the special lecturers, who continued to carry about $50 \%$ of library instruction sessions. To address this need, TLS created a three semester Research and Teaching Fellowship. Intended to create a community of learning, the fellowship offered an opportunity to turn the special lecturer positions from an institutional crutch to a virtuous system that would give back to the university and the profession. Rather than hiring these part-time instructors in the fall, fellows would start their program in the spring, when the amount of library instruction was less demanding. While the special lecturers were hired from semester to semester, fellows would commit to teaching and learning with TLS and the libraries at large for three semesters. The first semester would focus on developing teaching and research skills through teaching observations, coinstruction, weekly readings, and online discussion board posts; the second would strengthen their efficacy as instructors through independent teaching and formal observations; and the third would center on peer training, research, and assessment. 
Starting fellows in the spring would also alleviate the burden of training; senior fellows, who would be finishing their third semester, would be responsible for training junior fellows, who would be beginning their first. The fellowship offered an opportunity to improve the teaching experience for both first-year students and graduate student instructors; it would improve the freshman composition program by creating more confident teachers capable of leading engaging and individualized instruction sessions, and also give back to the profession by training conscientious and talented future librarians.

In May 2015, we hired our first cohort of four fellows and compressed the first semester of reading, discussion, co-teaching, and observation into a 10 -week summer program. We updated our lesson plan, made improvements to the assessment, and developed a more sophisticated rubric to analyze the "a-ha moment" responses. Finally, and perhaps most importantly, we renamed the program from "Library Day," which implied that information literacy was confined to a single day and was not an integrative part of the research and writing process, to the more general "Information Literacy for Freshman Composition."

\section{"A-ha Moment" Assessment: Fall 2015- Spring 2016}

In scaling up the program, one of the more substantial changes was to move away from Twitter as our collection method. Although it offered an effective platform for the pilot, expanding that model from the 12 sections in the pilot to nearly 200 sections created logistical challenges. From privacy settings, to data duplication, to the number of students who were (or more often were not) active on Twitter, there was no easy way to collect the amount of data needed using social media. In response, we transitioned data collection to Qualtrics, a proprietary tool for creating web-based surveys. To keep the spirit of the "a-ha moment," we continued to cap individual responses at a discrete number of characters, although we increased the cap slightly from 140 to 150 to allow a little more room for creativity. Switching from Twitter to Qualtrics has enabled us to collect more and better quality data. It also allowed for the addition of a customized field for students to identify their library instructor, which helps to analyze trends over the larger pool of data. The result is a short, quick assessment for students that provides rich data at the program and instructor levels.

\section{Methods}

In addition to updating the collection, the analysis method was also adjusted to provide a greater level of depth and specificity. In addition to using the dispositions from the ACRL Framework for Information Literacy, a "knowledge practice" was added to account for the students whose "a-ha moment" indicated a connection with a resource or search process rather than an attitude. The final rubric includes six dispositions, one knowledge practice, and two categories to account for responses that fall outside of these parameters: comfort with UMD Libraries, and "other." Together, the dispositions and knowledge practice represent all six frames. To account for the level of development within responses for a given category, we also added levels of developing, proficient, and advanced competency for each criterion.

\begin{tabular}{|c|c|c|c|}
\hline \multicolumn{4}{|c|}{ UMD Libraries Information Literacy Dispositions Rubric } \\
\hline & Developing (1) & Proficient (2) & Advanced (3) \\
\hline \multicolumn{4}{|c|}{ Authority is Constructed and Contextual } \\
\hline $\begin{array}{l}\text { Understands importance } \\
\text { of evaluating information } \\
\text { and demonstrates self- } \\
\text { awareness of individual } \\
\text { biases }\end{array}$ & $\begin{array}{l}\text { Writer acknowledges } \\
\text { information } \\
\text { evaluation as concept }\end{array}$ & $\begin{array}{l}\text { Writer articulates the } \\
\text { rationale or importance of } \\
\text { evaluating the credibility of } \\
\text { a source }\end{array}$ & $\begin{array}{l}\text { Writer demonstrates } \\
\text { the value of evaluating a } \\
\text { source, and indicates an } \\
\text { understanding of the role } \\
\text { of self-bias in the process }\end{array}$ \\
\hline \multicolumn{4}{|c|}{ Information Creation as Process } \\
\hline $\begin{array}{l}\text { Matches an information } \\
\text { need with an appropriate } \\
\text { resource }\end{array}$ & $\begin{array}{l}\text { Writer acknowledges } \\
\text { that different } \\
\text { resources are } \\
\text { available for research }\end{array}$ & $\begin{array}{l}\text { Writer identifies a type, } \\
\text { purpose, or title of a specific } \\
\text { resource }\end{array}$ & $\begin{array}{l}\text { Writer articulates how } \\
\text { a specific resource } \\
\text { addresses their individual } \\
\text { information need }\end{array}$ \\
\hline Information Has Value & & & \\
\hline
\end{tabular}




\begin{tabular}{|c|c|c|c|}
\hline \multicolumn{4}{|c|}{ UMD Libraries Information Literacy Dispositions Rubric } \\
\hline & Developing (1) & Proficient (2) & Advanced (3) \\
\hline $\begin{array}{l}\text { Respects the original ideas } \\
\text { of others }\end{array}$ & $\begin{array}{l}\text { Writer acknowledges } \\
\text { attribution methods }\end{array}$ & $\begin{array}{l}\text { Writer articulates the value } \\
\text { of attribution }\end{array}$ & $\begin{array}{l}\text { Writer articulates the } \\
\text { importance of attribution } \\
\text { and identifies resources } \\
\text { for help/attribution } \\
\text { methods }\end{array}$ \\
\hline \multicolumn{4}{|l|}{ Research as Inquiry } \\
\hline $\begin{array}{l}\text { Values intellectual curiosity } \\
\text { in developing questions; } \\
\text { consider research as } \\
\text { open-ended exploration } \\
\text { and engagement with } \\
\text { information }\end{array}$ & $\begin{array}{l}\text { Writer acknowledges } \\
\text { research as concept }\end{array}$ & $\begin{array}{l}\text { Writer acknowledges } \\
\text { research as process }\end{array}$ & $\begin{array}{l}\text { Writer articulates the } \\
\text { iterative process of } \\
\text { developing/defining a } \\
\text { research question }\end{array}$ \\
\hline \multicolumn{4}{|l|}{ Scholarship as Conversation } \\
\hline $\begin{array}{l}\text { Seeks out conversations } \\
\text { taking place in their } \\
\text { research area }\end{array}$ & $\begin{array}{l}\text { Writer acknowledges } \\
\text { that there are } \\
\text { different points of } \\
\text { view on a topic }\end{array}$ & $\begin{array}{l}\text { Writer articulates the need } \\
\text { to incorporate different } \\
\text { points of view }\end{array}$ & $\begin{array}{l}\text { Writer demonstrates the } \\
\text { value of incorporating } \\
\text { different points of view }\end{array}$ \\
\hline \multicolumn{4}{|c|}{ Searching as Strategic Exploration } \\
\hline $\begin{array}{l}\text { Designs and refines search } \\
\text { strategies as necessary }\end{array}$ & $\begin{array}{l}\text { Writer acknowledges } \\
\text { search strategies } \\
\text { for narrowing or } \\
\text { broadening }\end{array}$ & $\begin{array}{l}\text { Writer articulates specific } \\
\text { search strategies (such as } \\
\text { key terms, subject thesaurus, } \\
\text { etc...) }\end{array}$ & $\begin{array}{l}\text { Writer demonstrates } \\
\text { awareness of search } \\
\text { strategies and how } \\
\text { they can aid in student } \\
\text { research }\end{array}$ \\
\hline $\begin{array}{l}\text { Seeks guidance from } \\
\text { experts such as librarians, } \\
\text { researchers, and } \\
\text { professionals }\end{array}$ & $\begin{array}{l}\text { Writer acknowledges } \\
\text { assistance available }\end{array}$ & $\begin{array}{l}\text { Writer acknowledges } \\
\text { assistance available and } \\
\text { identifies ways to get in } \\
\text { contact with appropriate } \\
\text { professionals }\end{array}$ & $\begin{array}{l}\text { Writer articulates } \\
\text { specific ways appropriate } \\
\text { professionals can support } \\
\text { students }\end{array}$ \\
\hline \multicolumn{4}{|l|}{ Other } \\
\hline $\begin{array}{l}\text { Comfort with UMD library } \\
\text { website, physical spaces, or } \\
\text { specific library instructor }\end{array}$ & & & (c) (i) (2) \\
\hline Other & & & \\
\hline
\end{tabular}

Although, traditionally a rubric is used to evaluate a learning artifact by applying each of the categories, the dispositions rubric asks evaluators to assign each response to a single category and developmental level. To norm the rubric, we pulled a random sample of 50 from the more than 1,300 total responses from fall 2015, discussing each response as a group to determine which criteria and level of competency were best represented. Based on this discussion, we made slight modifications to the language in the levels of competency and reordered some of the dispositions to make the rubric easier to read. We also added a category for "comfort level with the library" and "other," to absorb responses that could not fit in any other criteria.
At the end of the semester, library instructors were given a copy of their students' responses. Each instructor evaluated their set of responses, assigning each to a criterion and the appropriate level of competency. In fall 2015, the first semester that we implemented this assessment process to scale, we added an extra level of scrutiny by having a second reviewer code each set of responses. Although we expected that reviewers would assign responses to the same criteria and that discrepancies would arise in the levels of competency within those criteria, we found there were disagreements as to which disposition or knowledge practice a single response was most indicative. The following semester, spring 2016, we resolved this issue by increasing the amount of responses put through the norming process and 
providing a list of examples for each criteria and level of competency. However, the discrepancy in the data analysis did have an impact on our results for fall 2015; because there were two sets of reviewers for each response, there are twice as many final ratings as responses gathered. The results for spring 2015 are accurate for the responses collected.

Results: Fall 2015

\begin{tabular}{|c|c|c|c|c|c|c|c|c|c|}
\hline \multicolumn{10}{|c|}{ Fall 2015 Information Literacy Dispositions } \\
\hline & & \multicolumn{2}{|c|}{ Advanced (3) } & \multicolumn{2}{|c|}{ Proficient (2) } & \multicolumn{2}{|c|}{ Beginning (1) } & \multicolumn{2}{|c|}{ Total } \\
\hline Rubric Criterion & Mean & $\begin{array}{c}\% \\
\text { students } \\
\end{array}$ & $\mathbf{n}$ & $\begin{array}{c}\% \\
\text { students } \\
\end{array}$ & $\mathbf{n}$ & \begin{tabular}{|c|}
$\%$ \\
students \\
\end{tabular} & $\mathbf{n}$ & $\%$ & $\mathbf{n}$ \\
\hline $\begin{array}{l}\text { Authority is } \\
\text { Constructed }\end{array}$ & 1.22 & $1 \%$ & 1 & $21 \%$ & 32 & $78 \%$ & 119 & $6 \%$ & 152 \\
\hline $\begin{array}{r}\text { Information Creation } \\
\text { as Process } \\
\end{array}$ & 1.43 & $5 \%$ & 67 & $34 \%$ & 478 & $62 \%$ & 872 & $58 \%$ & 1417 \\
\hline $\begin{array}{r}\text { Information Has } \\
\text { Value }\end{array}$ & 2.83 & $86 \%$ & 51 & $10 \%$ & 6 & $3 \%$ & 2 & $2 \%$ & 59 \\
\hline Research as Inquiry & 1.56 & $12 \%$ & 26 & $33 \%$ & 75 & $55 \%$ & 124 & $9 \%$ & 225 \\
\hline $\begin{array}{r}\text { Scholarship as } \\
\text { Conversation }\end{array}$ & 2.61 & $66 \%$ & 25 & $29 \%$ & 11 & $5 \%$ & 2 & $1.5 \%$ & 38 \\
\hline $\begin{array}{r}\text { Searching as } \\
\text { Strategic Exploration } \\
\end{array}$ & 1.50 & $7 \%$ & 39 & $36 \%$ & 204 & $57 \%$ & 319 & $22 \%$ & 562 \\
\hline Search Strategies & 1.51 & $7 \%$ & 29 & $37 \%$ & 156 & $56 \%$ & 233 & $17 \%$ & 418 \\
\hline Guidance & 1.47 & $7 \%$ & 10 & $33 \%$ & 48 & $60 \%$ & 86 & $6 \%$ & 144 \\
\hline Other & & & & & & & & $.5 \%$ & 137 \\
\hline Total & & $8 \%$ & 209 & $31 \%$ & 806 & $56 \%$ & 1438 & & \\
\hline
\end{tabular}

Results: Spring 2016

\begin{tabular}{|c|c|c|c|c|c|c|c|c|c|}
\hline \multicolumn{10}{|c|}{ Fall 2015 Information Literacy Dispositions } \\
\hline & & \multicolumn{2}{|c|}{ Advanced (3) } & \multicolumn{2}{|c|}{ Proficient (2) } & \multicolumn{2}{|c|}{ Beginning (1) } & \multicolumn{2}{|c|}{ Total } \\
\hline Rubric Criterion & Mean & $\begin{array}{c}\% \\
\text { students }\end{array}$ & n & $\begin{array}{c}\% \\
\text { students }\end{array}$ & n & $\begin{array}{c}\% \\
\text { students }\end{array}$ & n & $\%$ & $\mathrm{n}$ \\
\hline $\begin{array}{l}\text { Authority is } \\
\text { Constructed }\end{array}$ & 1.36 & $1 \%$ & 1 & $33 \%$ & 23 & $66 \%$ & 46 & $8 \%$ & 70 \\
\hline $\begin{array}{r}\text { Information } \\
\text { Creation as Process } \\
\end{array}$ & 1.40 & $4 \%$ & 23 & $31 \%$ & 173 & $64 \%$ & 355 & $59 \%$ & 551 \\
\hline $\begin{array}{r}\text { Information Has } \\
\text { Value }\end{array}$ & 1.17 & $0 \%$ & 0 & $17 \%$ & 4 & $83 \%$ & 19 & $2 \%$ & 23 \\
\hline Research as Inquiry & 1.27 & $4 \%$ & 2 & $20 \%$ & 11 & $76 \%$ & 42 & $6 \%$ & 55 \\
\hline $\begin{array}{r}\text { Scholarship as } \\
\text { Conversation }\end{array}$ & 1.69 & $23 \%$ & 3 & $23 \%$ & 3 & $54 \%$ & 7 & $1 \%$ & 13 \\
\hline $\begin{array}{r}\text { Searching as } \\
\text { Strategic Exploration } \\
\end{array}$ & 1.45 & $5 \%$ & 10 & $36 \%$ & 80 & $60 \%$ & 131 & $23 \%$ & 221 \\
\hline Search Strategies & 1.42 & $3 \%$ & 4 & $37 \%$ & 54 & $61 \%$ & 89 & $16 \%$ & 147 \\
\hline Guidance & 1.51 & $8 \%$ & 6 & $35 \%$ & 26 & $57 \%$ & 42 & $8 \%$ & 74 \\
\hline Other & & & & & & & & $.5 \%$ & 33 \\
\hline Total & & $4 \%$ & 39 & $30 \%$ & 294 & $62 \%$ & 600 & & \\
\hline
\end{tabular}




\section{Discussion}

While the coding of the responses takes place individually, reflection happens as a group. Reports are generated at two levels, one for each individual instructor and a second for the program as a whole. The granularity of reports allows us to see which dispositions or knowledge practices are being most often represented across all of the sessions. It also provides insight into individual praxis; if a particular instructor has a more challenging disposition represented more often in the responses for her sessions, or the responses consistently demonstrate a more advanced level of competency, we are able to talk through her instructional approach as a group to identify which pieces are resonating with students that could be applied to our teaching at a higher level.

Overall, including the assessment for both fall and spring semesters, students self-reported their most significant area of learning to be "information creation as process" (58\% and 59\%), which corresponds with their ability to match an information need with an appropriate library resource. The second most significant area, "searching as strategic exploration" (22\% and $23 \%$ ), relates to search strategies and the ability to seek guidance from experts. Very few results were indicative of the higher-level critical thinking skills, such as "authority is constructed and contextual" ( $6 \%$ and $8 \%$ ) or "information has value" (2\% and $2 \%)$. Within each of the categories, the majority of students performed at a "beginning" level (56\% and $62 \%$ ) and about a third of students performed at a "proficient" level (31\% and 30\%). Few students demonstrated an "advanced" level of competency for any of the criteria ( $8 \%$ and $4 \%$ ). However, while dispositions associated with higher-level thinking skills, such as "information has value," were less often represented, the students that did share responses indicative of those concepts tended to connect with those ideas more deeply (ex: $86 \%$ of f15 students performed at an "advanced" level when sharing responses related to "information has value").

In many ways, these results are appropriate for a first-year student audience visiting the library for the first time in their academic career. It is reasonable and appropriate that these students would perform at a developing or proficient level in any of these concepts, and the fact that some of the students were able to demonstrate an "advanced" level of competency in any of the criteria is impressive. It is also important to contextualize these results within the broader arc of our instruction program. Had we solicited these responses even a year earlier, it is probable that all of the responses would have centered on "information creation as process," or the ability to match an information need with the appropriate library resource. That approximately $40 \%$ of responses were indicative of other conceptual frameworks shows enormous growth in our instruction process. The consistency from fall and spring semesters and the continued emphasis by students on the research process gives us the impetus to continue developing our lesson plan and push ourselves to de-emphasize even further the attention given to database demonstrations and increase the amount of time spent on critical thinking and engagement with research questions.

\section{Limitations}

Although the "a-ha moment" did not provide a direct measure of student learning, the responses provided enormous insight into our program. Mapping the responses onto the rubric also enabled us to identify trends in the data that would have been difficult to spot. It should be noted that while we did go through a norming process each semester, the assigning of responses to categories and ranking of those responses continue to be subjective. Responses could have been impacted by how the library instructor introduced the assessment, when the library session occurred during the semester, and how the evaluator interpreted and ranked the results. The results provide a general, rather than specific, overview of what students found the most meaningful from the library sessions.

\section{Evaluating Student Artifacts: Fall 2016}

In fall 2016, we piloted an additional small-scale assessment project that incorporated student artifacts to assess the impact of the updated library instruction on the academic success of freshman composition students. The assessment project focused on the annotated bibliography, one of five required assignments for the course. The annotated bibliography was ideal for several reasons. First, it occurs early in the academic term. Students are often preparing for this assignment, or have recently completed it, during their visit to the library. Second, it provides a direct measure of a student's ability to identify, utilize, and synthesize the sources discussed during their library session. Finally, the annotated bibliography asks students to identify five scholarly and popular sources. The brevity of the assignment 
allows library instructors to read through the artifacts quickly, which was important given the ongoing commitment to assessment already taking place with the "a-ha moments."

To build continuity between our assessment and the assessment work occurring within the academic department, we chose to evaluate the bibliographies using a rubric currently in use by the Academic Writing Department. This rubric was developed in
2015 and is used by course instructors to assess their students' final position papers, which incorporate at least 20 sources. Although the rubric includes many criteria, three of these apply directly to information literacy: citation accuracy, selection of sources, and incorporation of sources.

The rubric below is provided courtesy of the University of Maryland Academic Writing Program.

\begin{tabular}{|c|c|c|c|c|}
\hline \multicolumn{5}{|c|}{ Excerpt from AWP Learning Outcomes Rubric-Fall 2015} \\
\hline & Advanced (3) & Proficient (2) & Developing (1) & Unacceptable (0) \\
\hline $\begin{array}{l}\text { Source } \\
\text { Quality }\end{array}$ & $\begin{array}{l}\text { Writer consistently } \\
\text { integrates a rich variety } \\
\text { of high quality and } \\
\text { scholarly research } \\
\text { relevant to his/her } \\
\text { argument. The writer } \\
\text { exceeds the audience's } \\
\text { expectations for } \\
\text { relevant sources. }\end{array}$ & $\begin{array}{l}\text { Writer employs research } \\
\text { that is credible and } \\
\text { relevant to his/her } \\
\text { argument. The writer } \\
\text { meets the audience's } \\
\text { expectations for } \\
\text { appropriate sources. }\end{array}$ & $\begin{array}{l}\text { Writer draws on sources } \\
\text { that are not consistently } \\
\text { relevant or credible. } \\
\text { Few of these sources } \\
\text { are scholarly. The writer } \\
\text { may misunderstand the } \\
\text { audience's expectations } \\
\text { for research, drawing on } \\
\text { inappropriate sources } \\
\text { or ignoring important } \\
\text { sources. }\end{array}$ & $\begin{array}{l}\text { Writer rarely integrates } \\
\text { research into his/her } \\
\text { essay, and/or when the } \\
\text { writer does integrate } \\
\text { sources, they are not } \\
\text { relevant, credible, or } \\
\text { scholarly. The writer } \\
\text { fails to meet the } \\
\text { audience's expectations } \\
\text { for relevant and } \\
\text { appropriate sources. }\end{array}$ \\
\hline $\begin{array}{c}\text { Source } \\
\text { Use }\end{array}$ & $\begin{array}{l}\text { Writer effectively and } \\
\text { expertly integrates } \\
\text { research into the } \\
\text { argument by means } \\
\text { of attribution, } \\
\text { summarizing, quoting, } \\
\text { or paraphrasing. } \\
\text { Writer thoroughly } \\
\text { analyzes research and } \\
\text { offers meaningful and } \\
\text { persuasive explanations } \\
\text { of how it relates to his/ } \\
\text { her argument. }\end{array}$ & $\begin{array}{l}\text { Writer judiciously } \\
\text { integrates research } \\
\text { into the argument by } \\
\text { means of attribution, } \\
\text { summarizing, quoting, } \\
\text { or paraphrasing. Writer } \\
\text { analyzes research and } \\
\text { explains how it relates } \\
\text { to his/her argument. }\end{array}$ & $\begin{array}{l}\text { Writer integrates } \\
\text { research into his/her } \\
\text { essay but attempts } \\
\text { at attribution, } \\
\text { summarizing, quoting, } \\
\text { or paraphrasing are } \\
\text { sometimes flawed. } \\
\text { Writer may include } \\
\text { quotations with no } \\
\text { framing language } \\
\text { when integrating } \\
\text { source material. The } \\
\text { connections between } \\
\text { the research and } \\
\text { argument may be } \\
\text { missing or tenuous. }\end{array}$ & $\begin{array}{l}\text { Writer's attempts at } \\
\text { summarizing, quoting, } \\
\text { or paraphrasing are } \\
\text { frequently flawed. } \\
\text { Writer may not } \\
\text { attribute sources or } \\
\text { frame quotations. The } \\
\text { writer may not make } \\
\text { connections between } \\
\text { the research and his/her } \\
\text { argument. }\end{array}$ \\
\hline Citation & $\begin{array}{l}\text { The writer expertly cites } \\
\text { sources, both citing } \\
\text { them correctly within } \\
\text { the text and using } \\
\text { correct conventions } \\
\text { throughout the works } \\
\text { cited list. }\end{array}$ & $\begin{array}{l}\text { The writer cites sources } \\
\text { in text and throughout } \\
\text { the works cited list. } \\
\text { There may be minor } \\
\text { errors in MLA citation. }\end{array}$ & $\begin{array}{l}\text { The writer attempts to } \\
\text { cite all sources in text } \\
\text { and throughout the } \\
\text { works cited list, but } \\
\text { there may be major } \\
\text { errors in MLA citation. }\end{array}$ & $\begin{array}{l}\text { The writer makes no } \\
\text { attempt to cite sources, } \\
\text { or the writer may } \\
\text { attempt to cite sources, } \\
\text { but there is no evidence } \\
\text { pattern or style for } \\
\text { citations. }\end{array}$ \\
\hline
\end{tabular}

\section{Methods}

Thirteen freshman composition instructors were invited to participate in this project. The target demographic included instructors who had worked with the library at least one semester prior. This choice was strategic: first, veteran instructors often bring their students to the library later in the semester than new instructors, which would 
provide an opportunity to evaluate annotated bibliographies submitted before and after library instruction. Second, veteran instructors have worked with the library and have a vested interest in our mutual success. The hope was these instructors would not only be more willing to participate, but would also encourage students to participate in a research project.

Students enrolled in sections led by instructors who agreed to participate were asked to sign an informed consent form, which was distributed during their library instruction session. The informed consent gave the instructor permission to share a copy of that student's work with a librarian for the purposes of assessment. Students were under no obligation to participate. After the library instruction session, course instructors were sent a numbered list of students from their sections who were 18 years or older and agreed to participate in the research. The instructors were asked to upload three bibliographies from specific numbered students from the list (numbers 2, 4, and 7) from each section of their course through an online form. Course instructors were offered the option to strip identifying student information from the artifacts before submitting, or to have the confidential details removed by a library staff member after submission. Unfortunately, although all 13 instructors agreed to participate and librarians distributed informed consent to each section they taught, only four of the instructors fulfilled their commitment to participate by submitting copies of their students' bibliographies post-session. As a result, our pilot includes a total of 12 student artifacts from these four instructors. Librarians applied the rubric provided by the Academic Writing Program to the bibliographies as a team, coming to a consensus on the ranking of each category.

\section{Results}

\begin{tabular}{|c|c|c|c|c|c|c|c|c|c|c|}
\hline \multicolumn{11}{|c|}{ Annotated Bibliography Assessment: Fall 2016} \\
\hline \multirow[b]{2}{*}{ Rubric Criterion } & \multirow[b]{2}{*}{ Mean } & \multicolumn{2}{|c|}{ Advanced (3) } & \multicolumn{2}{|c|}{ Proficient (2) } & \multicolumn{2}{|c|}{ Beginning (1) } & \multicolumn{2}{|c|}{ Unacceptable (0) } & \multirow[b]{2}{*}{ Total $n$} \\
\hline & & $\begin{array}{c}\% \\
\text { students }\end{array}$ & $\mathbf{n}$ & $\begin{array}{c}\% \\
\text { students }\end{array}$ & $\mathbf{n}$ & $\begin{array}{c}\% \\
\text { students }\end{array}$ & $\mathbf{n}$ & $\begin{array}{c}\% \\
\text { students }\end{array}$ & $\mathbf{n}$ & \\
\hline Source Quality & 2.66 & $67 \%$ & 8 & $33 \%$ & 4 & $0 \%$ & 0 & $0 \%$ & 0 & 12 \\
\hline Source Use & 2.12 & $42 \%$ & 5 & $33 \%$ & 4 & $25 \%$ & 3 & $0 \%$ & 0 & 12 \\
\hline Citation & 2.33 & $42 \%$ & 5 & $50 \%$ & 6 & $8 \%$ & 1 & $0 \%$ & 0 & 13 \\
\hline Total & & $47 \%$ & 18 & $42 \%$ & 16 & $10 \%$ & 4 & $0 \%$ & 0 & \\
\hline
\end{tabular}

\section{Discussion}

In our application of the academic writing rubric to the students' annotated bibliographies, we found that a slight majority of students (52\%) ranked in the "beginning" or "proficient" categories. None of the students ranked in the "unacceptable" category. Students ranked highest in the category "source quality" (with a mean of 2.66) and lowest in the category "source use" (with a mean of 2.12). Our sample size was too small to identify any significant difference in performance between students who attended a library instruction session prior to submitting their annotated bibliography versus students who attended a library instruction session after submitting their annotated bibliography. While this is in part due to the small number of respondents, this may also be related to the nature of the assignment, which has explicit instructions regarding source type and format, mitigating the number of citation errors and use of popular or internet-based sources.

\section{Limitations}

The two main limitations to this study were the IRB process and the reliance on the academic writing faculty to provide copies of student artifacts. Because we planned to share our results at the Library Assessment Conference, it was important to obtain informed consent from students. This proved to be a barrier to participation. It meant that we had to take time away from a library session to explain the informed consent document and ask students to read and sign. It also required additional steps between soliciting consent and obtaining copies of student artifacts. The only way to get copies of student work was to go through the course instructors, which left our study directly dependent on their continued participation. Although all 13 of the instructors we contacted agreed to be part of this project, only four supplied us with student artifacts. This resulted in a much smaller sample size than we had originally anticipated. 


\section{Future Directions}

We plan to build on the pilot by undertaking an assessment of freshman composition student artifacts on a larger scale. Starting in January 2017, our department will gain a full-time first year experience librarian who will oversee assessment of the library's freshman composition instruction. We would like to expand this assessment model to include each of the five required assignments for the course, collecting student artifacts and applying the AWP rubric to one assignment per year. The hope is that this continued assessment, combined with the on-going "a-ha moment" assessment, will help us identify at which points in the semester library instruction is most impactful.

To address the limitations of this study, we will lower the barrier to participation for students and course instructors. Future assessments, which will only be used within the department to improve our practice, will be able to proceed without the need for informed consent procedures, eliminating several steps between the introduction of the assessment to course instructors and the collection of student work. We also plan to collaborate more explicitly with the director of the program to publicize the assessment project and share results. Finally, one of the goals for the first year experience librarian is to become embedded in the AWP assessment, in which they apply an expanded version of the rubric to the students' final assignment for the semester, the position paper. Working together to share assessment processes and results will enable each department to gain a better understanding of how our assessment efforts can complement and reinforce one another.

\section{Conclusion}

The assessment of student learning on multiple levels has changed our approaches to teaching within the department, but also the library at large. Librarians have made radical changes to the teaching outline for freshman composition, emphasizing active learning and paring down the amount of resources discussed. The hiring and training of special lecturers was also transformed. Rather than hiring lecturers a few weeks before the start of the semester, the Research and Teaching Fellowship requires a three-semester commitment on behalf of participants, developing teaching skills over multiple semesters and providing a supportive learning environment for teachers and students. As a result of these changes, the relationship between the libraries and the composition program has improved. Composition students are retaining more information from the session and are engaging with material on a deeper level. Library instructors are more satisfied with their teaching experience, which creates opportunities for more positive interactions with students and course instructors.

-Copyright 2017 Rachel W. Gammons and Lindsay Inge 